\title{
Effect of Stapler Booster on Post-operative Air Leakage in the Surgical Treatment of Bullous Lung Disease
}

\section{Büllöz Akciğer Hastalığının Cerrahi Tedavisinde Stapler Güçlendirici Kullanmanın Postoperatif Hava Kaçağı Üzerine Etkisi}

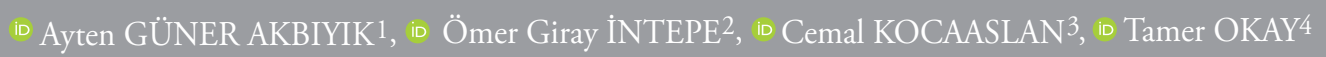

Iİstanbul Medeniyet University Faculty of Medicine Göztepe Training and Research Hospital, Clinic of Cardiac Surgery, İstanbul, Turkey

2İstanbul Medeniyet University Faculty of Medicine Göztepe Training and Research Hospital, Clinic of Thoracic Surgery, İstanbul, Turkey

${ }^{3}$ Kırklareli State Hospital, Clinic of Thoracic Surgery, Kırklareli, Turkey

${ }^{4}$ Dr. Siyami Ersek Thoracic and Cardiovascular Surgery Training and Research Hospital, Clinic of Thoracic Surgery, İstanbul, Turkey

\section{ABSTRACT}

Objective: Prolonged air leakage is a major complication of operations for bullous lung disease. This study aimed to investigate the effect of using buttressed staple lines on post-operative air leakage in patients who underwent bullous lung disease (BLD) surgery by comparing the use and non-use of buttressed staple lines.

Methods: This single-institution study included patients who underwent thoracotomy because of BLD between 2007 and 2015. Patients were retrospectively reviewed for demographic variables, operation technique, buttressed staple line usage and type and postoperative air leakage duration.

Results: We analysed 49 patients [44 (89\%) men], with a mean age of 59 years. Of patients, $97.9 \%(n=48)$ had wedge resection, and $2.1 \%(n=1)$ had lobectomy. In $44 \%(n=22)$, a buttressed staple line was used. Autografts (bulla wall) were used as buttressed staple lines in $54.5 \%(\mathrm{n}=12)$ and synthetic polytetrafluoroethylene grafts in $45.5 \%(\mathrm{n}=10)$ of cases. The mean post-operative air leakage duration was $7 \pm 3$ days in the buttressed staple line group and $8 \pm 6$ days in cases without booster. Prolonged air leakage was seen in 3 patients $(27 \%)$ in the buttressed staple line group and $11(25 \%)$ in the no booster group. There was no difference between the presence and absence of booster and between organic and synthetic graft usage.

\section{ÖZ}

Amaç: Uzamış hava kaçağı büllöz akciğer hastalığı (BAH) operasyonlarının majör komplikasyonlarından biridir. Bu çalışma büllöz akciğer hastalığı nedeniyle opere edilen hastalarda stapler güçlendirici kullanımının post operatif hava kaçağı üzerine olan etkisini araştırmak amacıyla planlandi.

Yöntemler: Tek merkezli yapılan bu çalışmada 2007-2015 yılları arasında $\mathrm{BAH}$ nedeniyle opere edilen olgular retrospektif olarak incelendi. Hastalar yaş, cinsiyet, komorbidite (kronik obstrüktif akciğer hastalığı, koroner arter hastalığı), sigara öyküsü, operasyon tekniği, stapler güçlendirici kullanımı ve çeşidi ile postoperatif hava kaçağının süresine bakılarak değerlendirildi.

Bulgular: Kırk dokuz hasta retrospektif olarak analiz edildi. Hastaların yaş ortalaması 59 idi (4879). Kayıtlı hastaların 44’ü erkekti (\%89). Operasyonların \%97'si $(n=48)$ Wedge rezeksiyon ve \%2'si $(n=1)$ lobektomi idi. Operasyonların \%44'ünde $(\mathrm{n}=22)$, stapler güçlendirici kullanılmıştı. Kullanılan stapler güçlendiricilerinin $\% 54,5^{\prime} \mathrm{i}(\mathrm{n}=12)$ otogreft (bül duvarı) ve $\% 45,5^{\prime} \mathrm{i}$ $(n=10)$ sentetik politetrafloroetilen greft idi. Stapler güçlendirici kullanılan hastalarda post operatif hava kaçağının ortalama süresi $7 \pm 3$ gün (1-19 gün), kullanılmayanlarda ise $8 \pm 6$ (1-25 gün) idi. Uzamış hava kaçağı stapler güçlendirici kullanılanlarda \%27 $(\mathrm{n}=3)$, kullanılmayanlarda ise \%25 ( $\mathrm{n}=11)$ olarak saptandı. Ayrıca yapılan ikili karşılaştırmalarda eşlik eden kronik obstrüktif akciğer hastalığının hastanede kalış süresini uzattığı tespit edildi.
Address for Correspondence: Ayten GÜNER AKBIYIK, İstanbul Medeniyet University Faculty of Medicine Göztepe Training and Research Hospital, Clinic of Thoracic Surgery, İstanbul, Turkey E-mail: aytenguner@yahoo.com ORCID ID: orcid.org/0000-0003-0177-2056
Received: 06.05.2020

Accepted: 08.08.2020

Cite this article as: Kocaaslan C, Güner Akbıyık A, İntepe ÖG, Okay T. Effect of Stapler Booster on Postoperative Air Leakage in the Surgical Treatment of Bullous Lung Disease. Bezmialem Science 2021;9(3):290-3. 
Conclusion: We concluded that the use of buttressed staple lines (autograft or synthetic graft) did not create a statistically significant difference in post-operative air leakage duration when compared with patients without booster.

Keywords: Lung diseases, lung injury, lung volume measurements
Sonuç: Çalışmamızda büllöz akciğer hastalarının cerrahi tedavisinde stapler güçlendirici (otogreft veya sentetik greft) kullanımının postoperatif hava kaçağı süresi üzerine istatistiksel olarak anlamlı bir fark yaratmadığı sonucuna ulaşılmıştır.

Anahtar Sözcükler: Akciğer hasarı, akciğer hastalıkları, akciğer volum ölçümleri

\section{Introduction}

Emphysema, smoking and fibrotic diseases of the lungs are the most common etiologies of bullous lung disease (BLD) and are usually seen in men of the middle-age group $(1,2)$. The most common complication of BLD is pneumothorax caused by the rupture of bullae into the pleural cavity (3). Wedge resection, bullectomy, bullae ligation and anatomic ligation should be performed for the surgical removal of bullous areas in the lung via thoracotomy, median sternotomy and video-assisted thoracoscopic surgery.

The most frequently preferred surgical approach for resecting the bullous area is wedge resection, which should be achieved with a buttressed or non-buttressed stapler device. Prolonged air leakage is a major complication of these surgical procedures (4-6). The use of bullae wall, bovine pericardium, polytetrafluoroethylene (PTFE) as a buttressed line and the resected lung is supposed to decrease air leakage and hospitalisation duration after wedge resection; however, the benefit of creating a buttressed line for preventing post-operative air leak is still controversial $(7,8)$. This study aimed to investigate the effect of using bullae wall as autograft and PTFE as a buttress on air leakage and hospitalisation duration for lung volume reduction surgery (LVRS) in cases with BLD and to compare the outcomes of these buttressed ones between each other and with a non-buttressed staple line.

\section{Methods}

This single-institution study included patients who underwent thoracotomy for BLD between 2007 and 2015. We retrospectively analysed 62 patients' data, and 49 of them were included in the study. The study received approval from the scientific and ethical study board of the hospital (Dr. Siyami Ersek Thoracic and Cardiovascular Surgery Training and Research Hospital 08/05/2015 - 5918), and informed consent was obtained from the patients according to guidelines of the Helsinki Declaration.

All operations were performed via thoracotomy. Age, gender, chronic obstructive pulmonary disease (COPD) and coronary artery disease (CAD) existence, smoking history, operation type, operation technique, post-operative air leakage duration, hospitalisation duration and other complications were documented. The use of buttressed lines during the operations was grouped as none (Group I) or used (Group II). Then, Group II was further subdivided as follows: bullae wall/autograft (Group IIa) and PTFE (Group IIb). The effects of using bullae wall and PTFE as a buttress on air leakage and hospitalisation duration for surgical treatment of BLD were investigated. The outcomes of Groups I and II were compared, and a subgroup analysis was applied for Group II.

For statistical analyses, the Number Cruncher Statistical System 2007 (Kaysville, Utah, USA) software was used. To evaluate the study data, descriptive statistical methods (mean, standard deviation, median, frequency, minimum and maximum) were used. Mann-Whitney $U$ test was used in the two-group comparison of parameters without normal distribution. To compare qualitative data, Fisher's exact test and Continuity Correction test (Yates corrected chi-square) were used. Significance was evaluated as $\mathrm{p}<0.05$.

\section{Results}

The mean age of the patients was 59 (range; 48-79) years, and $44(89.9 \%)$ out of 49 were men. Of patients, $31(63 \%)$ had a smoking history, 25 (51\%) had COPD and 12 (24\%) had CAD. Right-sided thoracotomy was performed in 33 (67.3\%) patients. Of patients, $48(97.9 \%)$ had wedge resection and 1 $(2.1 \%)$ lobectomy procedure. Stapler booster was used in 22 (44\%) patients: $6(27.2 \%)$ bullae wall and 16 (72.7\%) PTFE graft (Table 1). Post-operative complications were reported in $19(38.7 \%)$ patients. The most frequent complication was prolonged air leakage and detected in 17 (34.6\%) patients. The mean post-operative air leakage durations were $8 \pm 5$ (range; $1-25$ ) days for all groups, $8 \pm 6$ days for Group I, $7 \pm 3$ days for Group IIa and $7 \pm 3$ days for Group IIb.

Prolonged air leakage was noted in 33.3\% ( $n=9)$ of cases in Group I and 31.8\% ( $n=7)$ in Group II. There was no significant difference between Groups I and II $(\mathrm{p}=0.843)$ and between Groups IIa and IIb ( $\mathrm{p}=0.843$; Table 2).

The mean hospitalisation duration was $10 \pm 7$ (range; 3-40) days in the dual comparisons performed, and hospital stay duration was not different between the groups. Only the presence of COPD as concomitant comorbidity was found to increase hospitalisation duration significantly ( $\mathrm{p}=0.007$; Table 3$)$.

\section{Discussion}

Air leakage is a major complication seen in those who are operated because of BLD (6), with a prevalence of $37 \%$ in the literature (9), which is a score high enough to be considered. Therefore, we evaluated the effect of buttressed staple lines on post-operative air leakage. 


\section{Study Limitations}

Our study found that the use of buttressed (autograft or PTFE) staple lines in the surgical treatment of BLD did not affect post-operative air leakage and hospitalisation duration. We also reported that the presence of COPD increases hospitalisation duration.

In the National Emphysema Treatment Trial (NETT), there was no difference between cases in which a buttressed line was used or not in LVRS for post-operative prolonged air leakage and hospitalisation duration. The effect of using a buttressed staple line on prolonged air leakage was also investigated in the NETT in which 580 patients underwent LVRS (8). NETT investigators recorded the materials used for staple line buttressing as bovine pericardium and PTFE, and no buttressing materials were used in less than $5 \%$ of patients. They found no difference between patients with and without supported stapler lines for post-operative air leakage. In this study, it was stated that air leak was accompanied by LVRS in $90 \%$ of patients and often caused long hospitalisation duration. In contrast, other studies have shown that a supporting stapler line considerably reduces the length of post-operative air leakage, but this has not reduced hospitalisation duration. It was argued that the occurrence and duration of air leaks are dependent on the characteristics of the disease of patients and are not for specific surgical techniques. In contrast, there are studies showing that a supporting stapler line considerably reduces the length of post-operative air leakage, but this has not reduced hospitalisation duration $(7,8)$.

There are many comparative studies on the effects of using a buttressed staple line on post-operative air leaks $(10,11)$. Stammberger et al.(11) examined 65 patients who underwent LVRS and found that buttressing the staple line with bovine pericardium significantly shortened air leak duration and drainage time (12).

Drahush et al. (13) developed a standardised approach for air leak reduction (STAR) after lung resection. The following three independent factors were reported to reduce air leaks in this study: fissureless operative technique, staple line buttressing and protocol-driven chest tube management. A remarkable decrease in post-operative prolonged air leak was recorded in 475 patients using STAR for pulmonary resection.

\section{Conclusion}

In the literature, the effect of using a buttressed staple line

Table 1. Localisation, buttressed staple line types and operation methods for all cases

\begin{tabular}{|c|c|c|c|}
\hline \multirow{2}{*}{ Localisation $(n=49)$} & Right & 33 & 67.3 \\
\hline & Left & 16 & 32.7 \\
\hline \multirow{2}{*}{ Buttressed staple line type $(n=22)$} & Bullae wall/ autograft & 6 & 27.2 \\
\hline & PTFE & 16 & 72.8 \\
\hline \multirow{2}{*}{ Operation ( $n=49)$} & Wedge & 48 & 7.9 \\
\hline & Lobectomy & 1 & 2.1 \\
\hline
\end{tabular}

Table 2. The effect of using a buttressed staple line and its type on air leakage duration

\begin{tabular}{|c|c|c|c|c|}
\hline \multirow{2}{*}{\multicolumn{2}{|c|}{ Min - max }} & \multirow{2}{*}{\multicolumn{2}{|c|}{$\begin{array}{l}\text { Air leakage duration (days) } \\
\text { Mean } \pm \text { SD }\end{array}$}} & \multirow{2}{*}{$\mathrm{P}$} \\
\hline & & & & \\
\hline Buttressed staple line & $\begin{array}{l}\text { No }(n=27) \\
\text { Yes }(n=22)\end{array}$ & $\begin{array}{l}1-25 \\
1-19\end{array}$ & $\begin{array}{l}8 \pm 6 \\
7 \pm 3\end{array}$ & 0.843 \\
\hline $\begin{array}{l}\text { Auto graft } \\
\text { PTFE graft }\end{array}$ & $\begin{array}{l}\text { Yes }(n=6) \\
\text { Yes }(n=16)\end{array}$ & $\begin{array}{l}1-19 \\
1-19\end{array}$ & $\begin{array}{l}7 \pm 3 \\
7 \pm 3\end{array}$ & 0.843 \\
\hline
\end{tabular}

Table 3. The effect of concomitant CAD and presence of COPD on hospitalisation duration

\begin{tabular}{|c|c|c|c|c|}
\hline \multicolumn{2}{|c|}{ Median } & \multicolumn{3}{|c|}{ Hospitalisation duration (days) } \\
\hline Theuran & & \multicolumn{2}{|l|}{ Mean \pm SD } & $\mathrm{p}$ \\
\hline CAD & Yes $(n=12)$ & 5-32 (7) & $11 \pm 9.1$ & 0.930 \\
\hline COPD & Yes $(n=25)$ & $7-40$ (24) & $23.2 \pm 148$ & $0.007^{*}$ \\
\hline
\end{tabular}

CAD: Coronary artery disease, COPD: Chronic obstructive pulmonary disease, SD: Standard deviation 
on post-operative air leakage and hospitalisation duration is controversial. Our study showed that the use of a buttressed staple line (autograft or synthetic graft) did not achieve a significant difference in post-operative air leakage duration when compared with patients without booster. Randomised prospective studies with more patients are needed.

\section{Acknowledgements}

Thank you Mehmet Ünaldı, MD, and Emine Şeyma Denli Yalvaç, MD, for your help in reviewing the article.

\section{Ethics}

Ethics Committee Approval: Dr. Siyami Ersek Thoracic and Cardiovascular Surgery Training and Research Hospital 08/05/2015- 5918 .

Informed Consent: Informed consent was obtained from the patients according to guidelines of the Helsinki Declaration.

Peer-review: Externally peer reviewed.

\section{Authorship Contributions}

Surgical and Medical Practices: A.G.B., Ö.G.İ., Concept: A.G.B., C.K., T.O., Design: A.G.B., Ö.G.İ., C.K., T.O., Data Collection or Processing: A.G.B., Ö.G.İ., Analysis or Interpretation: A.G.B., C.K., T.O., Literature Search: A.G.B., Ö.G.İ., Writing: A.G.B., Ö.G.İ., C.K., T.O.

Conflict of Interest: No conflict of interest was declared by the authors.

Financial Disclosure: The authors declared that this study received no financial support.

\section{References}

1. Morgan MD, Denison DM, Strickland B. Value of computed tomography for selecting patients with bullous lung disease for surgery. Thorax 1986;41:855-62.

2. Laros CD, Gelissen HJ, Bergstein PG, Van den Bosch JM, Vanderschueren RG, Westermann CJ, et al. Bullectomy for giant bullae in emphysema. J Thorac Cardiovasc Surg 1986;91:63-70.
3. Deslauriers J, Beaulieu M, Després JP, Lemieux M, Leblanc J, Desmeules M. Transaxillary pleurectomy for treatment of spontaneous pneumothorax. Ann Thorac Surg 1980;30:569-74.

4. Van Raemdonck D, Ninane V. Lung volume reduction for severe emphysema: do we need a scalpel or a scope?European Respiratory Review 2010;19:242-7.

5. Weder W, Thurnheer R, Stammberger U, Bürge M, Russi EW, Bloch KE. Radiologic emphysema morphology is associated with outcome after surgical lung volume reduction. Ann Thorac Surg 1997;64:3139.

6. Bloch KE, Georgescu CL, Russi EW, Weder W. Gain and subsequent loss of lung function after lung volume reduction surgery in cases of severe emphysema with different morphologic patterns. J Thorac Cardiovasc Surg 2002;123:845-54.

7. McKenna RJ Jr, Fischel RJ, Brenner M, Gelb AF. Use of the Heimlich valve to shorten hospital stay after lung reduction surgery for emphysema. Ann Thorac Surg 1996;61:1115-7.

8. Miller JI Jr, Landreneau RJ, Wright CE, Santucci TS, Sammons BH. A comparative study of buttressed versus nonbuttressed staple line in pulmonary resections. Ann Thorac Surg 2001;71:319-22.

9. DeCamp MM, Blackstone EH, Naunheim KS, Krasna MJ, Wood DE, Meli YM, et al. Patient and surgical factors influencing air leak after lung volume reduction surgery: lessons learned from the National Emphysema Treatment Trial. Ann Thorac Surg 2006;82:197-206.

10. Tanaka F, Itoh M, Esaki H, Isobe J, Ueno Y, Inoue R. Secondary spontaneous pneumothorax. Ann Thorac Surg 1993;55:372-6.

11. Stammberger U, Klepetko W, Stamatis G, Hamacher J, Schmid RA, Wisser W, et al. Buttressing the staple line in lung volume reduction surgery: a randomized three-center study. Ann Thorac Surg 2000;70:1820-5.

12. Murray KD, Ho CH, Hsia JY, Little AG. The influence of pulmonary staple line reinforcement on air leaks. Chest 2002;122:2146-9.

13. Drahush N, Miller AD, Smith JS, Royer AM, Spiva M, Headrick JR Jr. Standardized Approach to Prolonged Air Leak Reduction After Pulmonary Resection. Ann Thorac Surg 2016;101:2097-101. 